\author{
모돈에 대한 생강 및 황금 분말 급여가 초유와 혈청의 항산화력과 IgG \\ 농도에 미치는 영향 \\ 이성대 ${ }^{1}$ 정현정 ${ }^{*}$ 김인철 ${ }^{1}$ 박준철 $^{1}$ 김상범 ${ }^{1}$ 조성백 ${ }^{1}$ 송영민 $^{2}$ \\ ${ }^{1}$ 농촌진흥청 국립축산과학원, ${ }^{2}$ 국립진주산업대학교 동물소재공학과
}

\title{
Effects of Dietary Ginger and Scutellaria Dry Powder on Antioxidant Capacity and IgG Concentration in Colostrum and Plasma of Sows
}

Sung Dae Lee ${ }^{1}$, Hyun Jung Jung ${ }^{1}$, In Cheul Kim ${ }^{1}$, Jun Cheol Park ${ }^{1}$, Sang Bum Kim ${ }^{1}$, Sung Back Cho ${ }^{1}$ and Young Min Song ${ }^{2}$

${ }^{1}$ Dairy Science Division, National Institute of Animal Science, RDA,

${ }^{2}$ Dept. of Animal Resources Technology, Jinju National University, Jinju City

\begin{abstract}
The objective of this study was to investigate the effects of dietary ginger and Scutellaria on antioxidant capacity and IgG concentration in plasma and colostrum of sows. Twenty-four sows (Landrace $\times$ Yorkshire) in parity 2 were assigned to 3 treatment groups ( 8 sows per treatment) from 30 day before farrowing up to weaning on day 21 after farrowing. The treatment diets included 1) CON (Basal diet), 2) GDP (0.3\% ginger dry powder was used as the replacement of wheat in basal diet) and 3) SDP ( $0.3 \%$ Scutellaria dry powder was used as the replacement of wheat in basal diet). No differences were found in antioxidant capacity and $\operatorname{IgG}$ concentration in plasma of sows among all the three treatments. Antioxidant capacity in colostrum was not affected by replacement of ginger and Scutellaria dry powder. IgG and protein concentration in colostrum was significantly higher $(\mathrm{P}<0.05)$ in GDP than that in CON and SDP. However, fat and lactose concentration were not affected by treatments. The total amino acid concentration in colostrum was significantly higher $(\mathrm{P}<0.05)$ in GDP than that in CON and SDP. Plasma antioxidant capacity was not affected by treatments in piglet on 0 day and 21 day, but tended to increase by supplementation of ginger. On 0 day, plasma IgG in piglet was not detected by replacement of ginger and Scutellaria dry powder. However, plasma IgG concentration in piglets on 21 day was significantly higher $(\mathrm{P}<0.05)$ in GDP than that in CON and SDP. These results indicate that colostrum IgG concentration in sows and plasma IgG concentration in piglets were improved by feeding ginger dry powder 30 days before farrowing in comparison to basal diet.
\end{abstract}

(Key words : Sow, Ginger, Antioxidant capacity, IgG, Colostrum)

\section{서 론}

양돈 생산성을 개선시키기 위한 근본적인 방안으로써 모돈의 번 식 및 포유능력을 개선시킬 수 있는 연구가 필요하다. 일반적으로 모돈의 유질과 유량은 자돈의 성장에 영항을 미치는 주요한 요인으 로 알려져 있으며(Hendrix 등, 1976; Göransson, 1990), Hendrix 등(1976)은 자돈의 폐사율과 모돈 초유의 $\mathrm{IgG}$ 농도가 높은 상관 관계를 나타낸다고 보고하였다. 신생자돈은 모체로부터 면역물질을 이행 받지 못한 상태로 태어나며, 어미로부터 초유를 공급받음으로 써 자체면역력을 갖게 된다(Rooke와 Bland, 2002). 따라서, 포유 모돈의 유질은 자돈의 성장에 커다란 영향을 미치기 때문에 모돈의
유질개선에 대한 연구가 시급한 실정이다.

항산화력을 함유하고 있는 물질이 자돈의 생산성에 영향을 미칠 수 있다고 일부 연구자들에 의해 보고되었다. Antipatis 등(2001) 은 비타민 $\mathrm{A}$ 가 결핍된 사료를 섭취한 모돈에서 생산된 자돈의 혈 장 $\mathrm{IgG}$ 농도가 감소된다고 보고하였다. 또한, 모돈에게 항산화 효 과가 있는 비타민 $\mathrm{E}$ 와 $\mathrm{C}$ 를 첨가한 사료를 급여한 결과 초유와 자 돈 혈청의 $\mathrm{IgG}$ 함량이 증가하였다(Pinelli-Saavedra 등, 2001).

음식재로로 많이 이용되고 있는 생강은 항산화 활성물질인 ginerol, shogaol, phenolic ketone 등을 함유하고 있다(Fuhrman 등, 2000). 생강에 함유되어 있는 [6]-ginerol은 trichloromethylperoxyl radical과 1.1-diphenyl-2- picrylhydrazyl(DPPH) radical

* Corresponding author: Hyun Jung Jung, Dairy Science Division, National Institute of Animal Science, RDA, Cheonan City, Korea. Tel: 041-580-3453, Fax: 041-580-3459, E-mail: hyjjung@korea.kr 
을 제거하여 linoleic acid autoxidation과 인지질 liposome의 과 산화를 익제시켜주는 기능을 갖고 있다(Aeschbach 등, 1994; Sekiwa 등, 2000). 또한, rat에서 생강의 급여가 췌장과 소장의 lipase 증 가를 촉진시키며 (Platel과 Srinivasan, 2000), human에서 생강 추 출물의 섭취는 위장관의 운동성을 개선시킨다(Micklefield 등, 1999).

한편, 한방 재료에 이용되고 있는 황금(Scutellaria Baicalensis Geogri)은 항산화물질인 baicalin, baicalein, wogonin 등이 함유 되어 있다(Ko 등, 1996). 이러한 유효물질들은 nitric oxide와 지 질 과산화물의 생성을 억제하는 효과를 나타낸다(Kim 등, 1999). 또한, 황금의 유효성분들은 항산화, 항바이러스, 항박테리아, 항염 증 등의 효과가 있다(Razina 등, 1989; Konoshima 등, 1992; Kubo 등, 1981; Mahmood 등, 1993). 황금의 주요성분인 baicalin 은 위장관에서 beta-glucuronidase에 의해서 baicalein으로 변형되 어 흡수 저장되고(Zhang 등, 2006), 흡수된 baicalein은 free radical 소거와 항산화 호과를 나타낸다(Heo 등, 2004).

천연물질인 생강과 황금에 함유되어 있는 유효성분들은 체내에 흡수되어 항산화 기능을 나타내는 것으로 알려져 있지만, 현재까지 이러한 물질들이 모돈의 유질과 자돈 면역력 개선에 관련한 연구는 미흡한 실정이다. 따라서, 본 연구에서는 생강과 황금 건조분말의 급여가 모돈의 유질과 자돈의 면역력에 미치는 영향을 검토하기 위 해서 수행하였다.

\section{재료 및 방법}

\section{1. 공시동물 및 시험사료}

공시동물은 일령과 체중이 비슷한 2산차 임신모돈(Landrace $\times$ Yorkshire)을 3처리, 처리당 8 두씩 24두를 공시하었다. 대조구 $(\mathrm{CON})$ 사료의 원료인 $0.3 \%$ 밀가루를 생강건조분말 $(\mathrm{GDP})$ 와 황금 건조분말 $(\mathrm{SDP})$ 로 대체하여 분만예정일 30 일 전부터 포유 21 일까 지 51 일간 모돈에게 급여하였다. 생강과 황금 건조분말은 원료물질 을 열풍건조기로 건조하여 분쇄하는 방법으로 준비되었다.

포유기 모돈의 영양소 요구량은 NRC (1998) 권장 수준 이상으 로 옥수수 대두박 위주로 시험사료를 배합하였고, 배합비율과 성 분은 Table 1에 나타내었다. 사료는 하루 2 회로 제한하여 아침과 저녁에 급여하였다. 분만 전일까지 $2.4 \mathrm{~kg} /$ 일, 분만 후 7 일까지 1.2 $\mathrm{kg} / \mathrm{day}$ 을 기본으로 날짜 경과에 따라 $0.32 \mathrm{~kg}$ 씩 추가 급여, 분만 후 8 일부터 자돈의 이유 21 일령까지 기본 $3.4 \mathrm{~kg}$ /일에 포유자돈 당 $0.20 \mathrm{~kg}$ 을 추가 급여하였다. 급수는 니플을 이용하였으며, 음수량에 는 제한을 두지 않았다. 분만예정일로부터 10 일 전에 임신모돈을 분만사로 이동시켰으며, 자동환경제어장치를 이용하여 환기 및 온 도를 조절하였다.
Table 1. Ingredient composition and chemical composition of the experimental diets (as-fed basis, \%)

\begin{tabular}{|c|c|c|c|}
\hline Ingredients & $\mathrm{CON}^{1)}$ & $\mathrm{GDP}^{1)}$ & $\mathrm{SDP}^{1)}$ \\
\hline Corn & 64.66 & 64.66 & 64.66 \\
\hline Soybean Meal & 20.50 & 20.50 & 20.50 \\
\hline Wheat Bran & 7.00 & 7.00 & 7.00 \\
\hline Soybean oil & 2.90 & 2.90 & 2.90 \\
\hline Molasses & 1.40 & 1.40 & 1.40 \\
\hline Limestone & 0.85 & 0.85 & 0.85 \\
\hline Calcium Phosphate & 1.20 & 1.20 & 1.20 \\
\hline Salt & 0.30 & 0.30 & 0.30 \\
\hline Lysine & 0.20 & 0.20 & 0.20 \\
\hline Hairagase & 0.20 & 0.20 & 0.20 \\
\hline Mix-vitamin + mineral $^{2)}$ & 0.33 & 0.33 & 0.33 \\
\hline Antibiotic (Tiamulin 39) & 0.08 & 0.08 & 0.08 \\
\hline Flavor & 0.08 & 0.08 & 0.08 \\
\hline Wheat & 0.30 & - & - \\
\hline Ginger dry powder & - & 0.30 & - \\
\hline Scutellaria dry powder & - & - & 0.30 \\
\hline Total & 100.00 & 100.00 & 100.00 \\
\hline \multicolumn{4}{|l|}{ Calculated value } \\
\hline Dry Matter, \% & 87.24 & 87.24 & 87.24 \\
\hline Crude protein, $\%$ & 15.10 & 15.10 & 15.10 \\
\hline Crude fat, $\%$ & 5.49 & 5.49 & 5.49 \\
\hline Crude fiber, $\%$ & 3.81 & 3.81 & 3.81 \\
\hline Crude ash, \% & 4.75 & 4.75 & 4.75 \\
\hline Calcium, \% & 0.81 & 0.81 & 0.81 \\
\hline Phosphorus, \% & 0.60 & 0.60 & 0.60 \\
\hline Total lysine, $\%$ & 0.89 & 0.89 & 0.89 \\
\hline Total methionine+Cysteine, $\%$ & 0.50 & 0.50 & 0.50 \\
\hline Digestible energy, $\mathrm{kcal} / \mathrm{kg}$ & 3,400 & 3,400 & 3,400 \\
\hline
\end{tabular}

${ }^{1)} \mathrm{CON}$, basal diet; GDP, included ginger dry powder; SDP, included scutellaria dry powder

${ }^{2)}$ Supplied per kg diet : Vit A 5,000,000 IU, Vit $\mathrm{D}_{3} 1,000,000 \mathrm{IU}$, Vit E $1,000 \mathrm{mg}$, Vit $B_{1} 150 \mathrm{mg}$, Vit $B_{2} 300 \mathrm{mg}$, Vit $B_{12} 1,500 \mathrm{mg}$, Niacin amide $1,500 \mathrm{mg}$, DL-calcium phatothenate 1,000 mg, Folic acid $200 \mathrm{mg}$, Vit $\mathrm{H} 10 \mathrm{mg}$, Choline chloride 2,000 mg, Mn $3,800 \mathrm{mg}$, Zn 1,500 mg, Fe $4000 \mathrm{mg}$, Cu $500 \mathrm{mg}$, I $250 \mathrm{mg}$, Co $100 \mathrm{mg}, \mathrm{Mg} 200 \mathrm{mg}$. 


\section{2. 혈액샘플의 준비}

신생자돈 1 두가 분만이 완료되는 시점에 모돈 혈액은 이정맥, 자 돈 혈액은 분만 당일( 0 일)과 분만 후 21 일령에 대정맥에서 Heparin 진공튜브(Becton Dickinson, Co., USA)에 $10 \mathrm{ml}$ 을 각 각 채취하였다. 채취한 혈액은 $2000 \times \mathrm{g}$ 로 $4^{\circ} \mathrm{C}$ 서 15 분간 원심분 리하여 혈장을 분리하였으며, 분리된 혈장은 분석 전까지 $-4^{\circ} \mathrm{C}$ 냉동고에 보관되었다.

\section{3. 초유샘플의 준비}

초유는 모돈에 대한 채혈을 완료한 후에 손으로 직접 짜는 방법 으로 Falcon tube에 $50 \mathrm{ml}$ 을 채취하였다. 채취된 초유 중 $40 \mathrm{ml}$ 은 모유 내 아미노산, $\mathrm{IgG}$, 항산화력 분석을 위해 $-4^{\circ} \mathrm{C}$ 냉동고에 보관되었으며, 나머지 $10 \mathrm{ml}$ 은 모유의 일반성분 분석에 이용되었다.

\section{4. 시료분석 방법}

혈액과 초유 시료에서의 항산화력(mM Trolox)은 Antioxidant Assay kit(Cayman chemical, Cat. No. 7090001, USA)와 Microplate reader(VersaMax, Molecular Devices Inst., USA)를 이용하여 측정하였다. 항산화력 분석을 위하여 분석시료와 Trolox 표준액을 각각의 well에 $10 \mu$ | 첨가한 후에 metmyoglobin 10 $\mu \ell+$ chromogen $150 \mu \ell$ 추가로 첨가하였다. 그 후, 1 분 이내에 Hydrogen peroxide solution $40 \mu \ell$ 첨가한 다음, Plate cover를 덮고 5분간 상온에 반응시킨 후에 Microplate reader로 파장 750 $\mathrm{nm}$ 에서 측정하여 검량선을 작성하고 시료의 농도를 계산하였다. $\mathrm{IgG}$ 함량 $(\mathrm{mg} / \mathrm{ml})$ 은 Porcine $\mathrm{IgG}$ kit(ECOS Inst., Cat. No. P0303-1, Japan)를 이용해 측정하였다.
초유의 유성분은 자동유성분분석기 (Lacto scope, Delta Inst., Netherlands)를 이용해 분석하였다. 유리 아미노산 분석을 위해 초 유 $200 \mu \ell$ | $6 \mathrm{~N} \mathrm{HCl}$ 을 가하여 진공 밀봉한 후, $110^{\circ} \mathrm{C}$ 서 24시 간 동안 가수분해를 실시하였다. 가수분해 후 시료를 speed vacuum concentration (Mivac concentrator Range, Genevac Limited, $\mathrm{UK}$ )로 감압 농축하여 $\mathrm{HCl}$ 을 제거하고 $\mathrm{pH}$ 2.2의 sodium citrate loading buffer로 희석한 후 $0.2 \mu \mathrm{m}$ syring filter (GelmanSciences, USA)로 여과한 다음 amino acid analyzer (Biochrom 20, Pharmacia, Sweden)을 이용하여 분석하였다.

\section{5. 모돈 및 자돈 생산성 조사}

모돈과 자돈의 생산성을 조사하기 위해서 모돈의 총산자수, 포유 개시 두수와 체중 그리고 이유 두수와 체중을 조사하였다. 자돈의 일당증체량은 포유개시 체중과 이유(21일령) 체중의 차이를 사육 일수로 나누어 계산하였다.

\section{6. 통계분석}

시험에서 얻어진 모든 결과는 SAS(1995)의 GLM(General Linear Model) 방법으로 분석하였다. 처리간의 평균은 Duncan의 Multiple Range Test를 이용하여 비교하였다.

\section{결 과}

1. 항산화력 및 면역글로불린 $\mathrm{G}(\mathrm{lgG})$

분만 전 30일부터 생강 건조분말(GDP)과 황금 건조분말(SDP)을 섭취한 모돈 혈액과 초유에서의 항산화력과 $\operatorname{IgG}$ 함량은 Table 2에

Table 2. Effect of supplementation with ginger and scutellaria on antioxidant (mM Trolox) and IgG concentration $(\mathrm{mg} / \mathrm{ml})$ in sow plasma and colostrum

\begin{tabular}{lcccc}
\hline Items & CON $^{1)}$ & GDP $^{1)}$ & SDP $^{1)}$ & SEM $^{2}$ \\
\hline \hline Sow plasma & & & & \\
Antioxidant & 2.37 & 2.59 & 2.63 & 0.08 \\
IgG & 13.58 & 12.10 & 12.26 & 0.35 \\
\hline Colostrum & & & & \\
Antioxidant & 0.85 & 1.20 & 1.04 & 0.07 \\
IgG & $40.81^{\mathrm{b}}$ & $54.28^{\mathrm{a}}$ & $41.25^{\mathrm{b}}$ & 1.81 \\
\hline
\end{tabular}

\footnotetext{
${ }^{1)} \mathrm{CON}$, basal diet; GDP, included ginger dry powder; SDP, included scutellaria dry powder

${ }^{2)}$ Pooled standard error of mean values $(\mathrm{n}=24)$

${ }^{\mathrm{a}, \mathrm{b}}$ Means with different superscripts in the same row are different at $\mathrm{P}<0.05$.
} 
나타내었다. 모돈 혈청에서 항산화력과 $\mathrm{IgG}$ 는 처리구간에 유의적 인 차이를 나타내지 않았다. 초유에서 항산화력은 GDP와 SDP가 $\mathrm{CON}$ 보다 높은 수치를 나타내었지만, 처리구간의 유의적 차이를 나타네지 않았다. 초유의 $\mathrm{IgG}$ 함랑은 $\mathrm{GDP}$ 구가 다른 구에 비해 유 의적으로 높게 나타내었다 $(\mathrm{P}<0.05)$.
2. 초유의 유성분 및 아미노산 조성

생강 건조분말 $(\mathrm{GDP})$ 과 황금 건조분말 $(\mathrm{SDP})$ 을 분만 전 30 일부 터 섭취한 모돈 초유의 유성분과 아미노산 분석 결과는 Table 3 과 4에 나타내었다. 유성분에서, 건물 함량은 GDP구가 높았지만, 처

Table 3. Effect of supplementation with ginger and scutellaria on chemical composition in sow's colostrum(\%)

\begin{tabular}{lcccc}
\hline Items & CON $^{1)}$ & GDP $^{1)}$ & SDP $^{1)}$ & SEM $^{2)}$ \\
\hline \hline Dry matter & 23.44 & 26.11 & 23.27 & 0.55 \\
Protein & $13.60^{\mathrm{b}}$ & $16.30^{\mathrm{a}}$ & $13.60^{\mathrm{b}}$ & 0.37 \\
Fat & 4.85 & 5.01 & 4.56 & 0.44 \\
Lactose & 3.00 & 2.71 & 3.11 & 0.08 \\
\hline
\end{tabular}

\footnotetext{
${ }^{1)} \mathrm{CON}$, basal diet; GDP, included ginger dry powder; SDP, included scutellaria dry powder

${ }^{2)}$ Pooled standard error of mean values $(\mathrm{n}=24)$

${ }^{\mathrm{a}, \mathrm{b}}$ Means with different superscripts in the same row are different at $\mathrm{P}<0.05$.
}

Table 4. Effect of supplementation with ginger and scutellaria on amino acid composition in sow's colostrum (\%)

\begin{tabular}{lcccc}
\hline Items & CON $^{\mathrm{l}}$ & $\mathrm{GDP}^{\mathrm{l}}$ & $\mathrm{SDP}^{1)}$ & SEM $^{2}$ \\
\hline \hline Cysteine (Cys) & $0.29^{\mathrm{b}}$ & $0.36^{\mathrm{a}}$ & $0.29^{\mathrm{b}}$ & 0.01 \\
Methionine (Met) & $0.20^{\mathrm{b}}$ & $0.24^{\mathrm{a}}$ & $0.20^{\mathrm{b}}$ & 0.01 \\
Aspartic acid (Asp) & $1.23^{\mathrm{b}}$ & $1.46^{\mathrm{a}}$ & $1.25^{\mathrm{b}}$ & 0.03 \\
Threonine (Thr) & $0.86^{\mathrm{b}}$ & $1.05^{\mathrm{a}}$ & $0.87^{\mathrm{b}}$ & 0.03 \\
Serine (Ser) & $0.97^{\mathrm{b}}$ & $1.18^{\mathrm{a}}$ & $0.98^{\mathrm{b}}$ & 0.03 \\
Glutamic acid (Glu) & $2.42^{\mathrm{b}}$ & $2.86^{\mathrm{a}}$ & $2.46^{\mathrm{b}}$ & 0.06 \\
Glycine (Gly) & $0.50^{\mathrm{b}}$ & $0.61^{\mathrm{a}}$ & $0.52^{\mathrm{b}}$ & 0.01 \\
Alanine (Ala) & $0.59^{\mathrm{b}}$ & $0.73^{\mathrm{a}}$ & $0.62^{\mathrm{b}}$ & 0.02 \\
Valine (Val) & $0.76^{\mathrm{b}}$ & $0.92^{\mathrm{a}}$ & $0.79^{\mathrm{b}}$ & 0.02 \\
Isoleucine (Ile) & $0.39^{\mathrm{b}}$ & $0.46^{\mathrm{a}}$ & $0.40^{\mathrm{b}}$ & 0.01 \\
Leucine (Leu) & $1.42^{\mathrm{b}}$ & $1.69^{\mathrm{a}}$ & $1.46^{\mathrm{b}}$ & 0.04 \\
Tyrosine (Tyr) & $0.65^{\mathrm{b}}$ & $0.79^{\mathrm{a}}$ & $0.66^{\mathrm{b}}$ & 0.02 \\
Phenylalanine (Phe) & $0.60^{\mathrm{b}}$ & $0.73^{\mathrm{a}}$ & $0.63^{\mathrm{b}}$ & 0.02 \\
Lysine (Lys) & $0.98^{\mathrm{b}}$ & $1.16^{\mathrm{a}}$ & $1.00^{\mathrm{b}}$ & 0.03 \\
Histidine (His) & $0.33^{\mathrm{b}}$ & $0.39^{\mathrm{a}}$ & $0.34^{\mathrm{b}}$ & 0.01 \\
Arginine (Arg) & $0.73^{\mathrm{b}}$ & $0.86^{\mathrm{a}}$ & $0.71^{\mathrm{b}}$ & 0.02 \\
Proline (Pro) & $1.27^{\mathrm{b}}$ & $1.56^{\mathrm{a}}$ & $1.29^{\mathrm{b}}$ & 0.03 \\
Sum & $14.19^{\mathrm{b}}$ & $17.04^{\mathrm{a}}$ & $14.50^{\mathrm{b}}$ & 0.38 \\
\hline
\end{tabular}

${ }^{1)} \mathrm{CON}$, basal diet; GDP, included ginger dry powder; SDP, included scutellaria dry powder

${ }^{2)}$ Pooled standard error of mean values $(\mathrm{n}=24)$

${ }^{\mathrm{a}, \mathrm{b}}$ Means with different superscripts in the same row are different at $\mathrm{P}<0.05$. 
리구간에 유의적인 차이를 나타내지 않았다. 단백질 함량은 GDP 구가 다른 구에 비해 유의적으로 높았다 $(\mathrm{P}<0.05)$. 지방과 유당 함 량은 처리구간에 유의적 차이를 나타내지 않았다. 아미노산 조성에 서, $\mathrm{GDP}$ 구가 다른 구에 비해 각각의 아미노산 함량과 총 아미노 산 함량이 유의적으로 높게 함유되어 있었다 $(\mathrm{P}<0.05)$. GDP의 초 유 아미노산 조성에서 Glutamic acid가 $2.86 \%$ 로 가장 많이 함유 되어 있고, Aspartic acid, Threonine, Serine, Leucien, Lysine, Proline가 $1.05 \%$ 이상 함유하고 있다.

\section{3. 자돈 혈청의 항산화력과 IgG 함량}

임신 모돈의 분만 전 30 일부터 생강 건조분말(GDP)과 황금 건 조분말 $(\mathrm{SDP})$ 를 섭취한 모돈에서 생산된 자돈 혈청의 항산화력과 $\mathrm{IgG}$ 함량은 Table 5에 나타내었다. 0 일령과 21 일령에서 자돈 혈
청의 항산화력은 처리구간에 유의적 차이를 나타내지 않았지만, 다 른 구에 비해 GDP구가 높은 함량을 유지하였다. IgG 함량은 0 일 령에서는 측정되지 않았고, 21 일령에서는 $\mathrm{GDP}$ 구가 다른 구에 비 해 유의적으로 높은 함량을 나타내었다 $(\mathrm{P}<0.05)$.

\section{4. 모돈 번식 성적 및 자돈 성장}

분만 전 30 일부터 생강건조분말과 황금건조분말을 섭취한 모돈 에서 생산된 자돈 두수, 생시체중 그리고 일당증체랑은 Table 6에 나타내었다. 모돈의 총산자수, 이유두수는 처리구간에 유의적 차이 를 나타내지 않았고, 자돈의 생시체중과 21 일령 체중은 처리구간에 유의적 차이를 나타내지 않았지만, 생강건조분말구가 다른 구에 비 해 높게 나타내었다. 일당증체랑은 생강건조분말구가 $222.89 \mathrm{~g} /$ day 로 $\mathrm{CON} 186.68 \mathrm{~g} / \mathrm{day}$ 보다 $16.2 \%$ 개선되었다.

Table 5. Effect of supplementation with ginger and scutellaria on antioxidant and IgG concentration in piglet plasma at 0 and 21 day

\begin{tabular}{lccccc}
\hline Items & Day & $\mathrm{CON}^{1)}$ & $\mathrm{GDP}^{1)}$ & $\mathrm{SDP}^{1)}$ & $\mathrm{SEM}^{2)}$ \\
\hline \hline \multirow{2}{*}{ Antioxidant, mM Trolox } & 0 & 0.86 & 1.22 & 1.14 & 0.07 \\
& 21 & 1.49 & 1.68 & 1.53 & 0.04 \\
\hline \multirow{2}{*}{$\mathrm{ggG}, \mathrm{mg} / \mathrm{ml}$} & 0 & $\mathrm{nd}^{3)}$ & $\mathrm{nd}$ & $\mathrm{nd}$ & \\
& 21 & $14.00^{\mathrm{b}}$ & $15.46^{\mathrm{a}}$ & $13.96^{\mathrm{b}}$ & 0.19 \\
\hline
\end{tabular}

${ }^{1)} \mathrm{CON}$, basal diet; GDP, included ginger dry powder; SDP, included scutellaria dry powder

${ }^{2)}$ Pooled standard error of mean values $(\mathrm{n}=24)$

3) nd, Not detected

${ }^{\mathrm{a}, \mathrm{b}}$ Means with different superscripts in the same row are different at $\mathrm{P}<0.05$.

Table 6. Effect of supplementation with ginger and scutellaria on sow reproduction and litter performance

\begin{tabular}{lcccc}
\hline Items & CON $^{1)}$ & GDP $^{1)}$ & SDP $^{1)}$ & SEM $^{2)}$ \\
\hline \hline No. of pigs total born per litter & 11.86 & 10.57 & 11.13 & 0.55 \\
No. of pigs suckled per litter & 9.71 & 10.29 & 9.63 & 0.39 \\
No. of pigs weaned per litter & 9.57 & 10.00 & 9.63 & 0.36 \\
Piglet weight on 0 d, kg & 1.48 & 1.58 & 1.56 & 0.05 \\
Piglet weight on 21 d, kg & 5.39 & 6.30 & 5.96 & 0.22 \\
Piglet weight gain, g/d & 186.68 & 222.89 & 207.55 & 9.17 \\
\hline
\end{tabular}

${ }^{1)} \mathrm{CON}$, basal diet; GDP, included ginger dry powder; SDP, included scutellaria dry powder

${ }^{2)}$ Pooled standard error of mean values $(n=24)$. 


\section{고 찰}

일반적으로 모유의 $\operatorname{IgG}$ 는 혈액으로부터 공급된다(Akers, 2002). 본 연구에서 생강 건조분말을 섭취한 모돈 초유의 $\mathrm{IgG}$ 함량이 증 가되는 결과를 나타내었다. 생강에 함유되어 있는 유용물질인 gingerol, shogaol, phenolic ketone 등은 동물 체내에서 항산화 효과를 나타낸다(Fuhrman 등, 2000; Sekiwa 등, 2000). 이리한 항산화 효과는 모유 합성과 분비에 필요한 에너지와 산소 요구량 증가로 발생된 활성산소를 제거하여 유선에서 모유 합성과 분비를 원활하게 한다(Sordillo, 2005). 또한 생강에 함유되어 있는 이들 물질은 arachidonic acid, adenosine diphosphate, epinephrine 그 리고 collagen에 의해 유래되는 혈소판 응집을 억제하는 효과가 있 으며(Koo 등, 2001; Chrubasik 등, 2005), 혈관 수축과 확장 작 용을 조절하는 기능이 있다 (Afshari 등, 2007). 그러므로 생강의 유용물질들에 의해 체내에서 혈류량이 증가되고 혈액에서 유선으로 $\mathrm{IgG}$ 공급이 충분히 공급되었기 때문에 초유의 $\mathrm{IgG}$ 함량이 증가된 것으로 사료된다. Pinelli-Saavedra 등(2001)은 모돈 사료에 항산 화 효과가 있는 비타딘 $\mathrm{E}$ 와 $\mathrm{C}$ 를 급여한 시험에서 초유의 $\mathrm{IgG}$ 함 량이 증가되었다고 보고하였다. 본 시험에서도 모돈의 생강 건조분 말 섭춰로 초유의 $\operatorname{IgG}$ 함량이 증가된 결과와 유사하게 나타내었다. 모돈의 생강 건조분말 섭취로 초유의 단백질 함량이 증가되었다. Dügenci 등 (2003)은 무지개송어에 생강 $1 \%$ 첨가한 사료를 3주간 급여한 시험에서 비특이 면역 반응이 증가한다고 보고하였다. 비득 이 면역 반응에 의해 모돈 초유의 $\mathrm{IgG}$ 와 단백질 함량이 증가된다 고 Krakowski 등(2002)이 보고하였다. 생강에 함유하고 있는 gingerol, shogaol, phnolic ketone 등에 의해 모돈의 비특이 면역 반응에 영향을 주어 초유의 단백질과 $\mathrm{IgG}$ 를 증가시킨 것으로 사료 되며 Krakowski 등 (2002)과 일치하는 결과를 나타내었다. 생강건 조분말을 섭취한 모돈 초유의 아미노산 조성이 대조구와 황금건조 분말구에 비해 유의적으로 놀은 것은 초유의 단백질 함량이 증가되 었기 때문에 나타난 결과이다.

자돈 0 일령 혈장에서 $\operatorname{IgG}$ 함량이 검출되지 않은 이유는 모돈의 태반으로부터 태아에게 면역물질인 $\mathrm{IgG}$ 를 공급할 수 없기 때문이 다(Rooke와 Bland, 2002). 신생자돈은 초유로부터 면역물질인 $\mathrm{IgG}$ 를 공급받아야만 자체 면역력을 생성시킬 수 있고(Hendrix 등, 1976), 외부 질병에 대한 방어력을 키울 수 있다(Tuchscherer 등, 2000). 자돈 21 일령 혈장에서 $\operatorname{IgG}$ 함량이 생강 건조분말을 섭취한 모돈의 자돈에서 높게 나타난 원인은 초유의 $\operatorname{IgG}$ 함량과 관련이 있는 것으로 사료된다. Rooke와 Bland (2002)는 자돈의 IgG 함량 은 모돈 초유의 $\operatorname{IgG}$ 함량에 의해 영향을 받는다고 보고하였다. 항 산화력은 처리구간에 유의적 차이를 나타내지 않았지만, 생강 건조 분말을 섭취한 모돈의 자돈에서 대조구와 황금 건조분말 섭취구보
다 높게 나타났다. 항산화력에서 유의적 차이가 발생되지 않은 원 인으로 생강분말의 첨가 수준이 낮았기 때문에 나타난 것으로 사료 되지만, 추가적으로 생강분말 첨가 수준에 따른 초유의 항산화력과 $\mathrm{IgG}$ 에 대해 연구가 필요할 것으로 사료된다.

자돈의 일당증체량에서 유의적 차이는 나타나지 않았지만, 생강 건조분말구가 다른 구에 비해 높게 나타난 결과는, 모돈의 생강 건 조분말 섭취에 의해 초유의 $\operatorname{IgG}$ 함량을 개선시커 신생자돈에게 충 분한 $\mathrm{IgG}$ 를 공급하였기 때문에 외부 질병에 대한 저항성이 증가되 어 일당증체량에 영향을 준 것으로 사료된다. 초유의 $\operatorname{IgG}$ 함량은 신생자돈의 성장률과 폐사율에 영향을 준다(Blecha 등, 1986; Krakowski 등 1998). 하지만, 유의적 효과가 나타나지 않았으므로 초유와 자돈의 성장에 관련한 추가적인 연구가 필요한 것으로 사료 된다.

이상의 결과를 요약하면, 생강에 함유되어 있는 유용물질들이 모 돈 초유의 $\mathrm{IgG}$ 와 단백질 함량을 개선시키고, 자돈의 $\mathrm{IgG}$ 함량을 증가시키는 효과를 확인할 수 있었다. 따라서 생강분말 첨가는 모 돈의 유질개선과 자돈 면역력 증가를 위해 활용할 수 있다.

\section{요 약}

본 연구에서는 생강과 황금 건조 분말의 급여가 모돈의 유질과 자돈의 면역력에 미치는 영향을 구명하고자 수행하였다. 공시동물 은 2산차 F1 임신모돈 24두를 이용하였다. 시험사료는 대조구 $(\mathrm{CON})$ 사료에 생강건조분말 $(\mathrm{GDP})$ 과 황금건조분말 $(\mathrm{SDP})$ 를 0.3 $\%$ 대체하여 분만 전 30 일부터 이유 21 일까지 시험사료를 급어하 였다. 모돈 혈청에서 항산화력과 $\mathrm{IgG}$ 는 처리구간에 유의적인 차이 를 나타내지 않았다. 초유에서 항산화력은 처리구가 대조구보다 높 은 수치를 나타내었지만, 처리구간의 유의적 차이를 나타내지 않았 다. 초유의 $\mathrm{IgG}$ 함량은 $\mathrm{GDP}$ 구가 다른 처리구에 비해 유의적으로 놀게 나타났다 $(\mathrm{P}<0.05)$. 초유의 유성분 함량에서, 단백질 함량은 $\mathrm{GDP}$ 구가 다른 처리구에 비해 유의적으로 높게 함유하였다 $(\mathrm{P}<0.05)$. 지방과 유당 함량은 처리구간에 유의적 차이를 나타내지 않았다. 초유의 아미노산 조성은 $\mathrm{SDP}$ 구가 다른 처리구에 비해 각 각의 아미노산 함량이 유의적으로 높게 나타났다. 0 일령과 21일령 에서 자돈 혈청의 항산화력은 처리구간에 유의적 차이를 나타내지 않았지만, 다른 구에 비해 GDP구가 높은 함량을 유지하였다. $\mathrm{IgG}$ 함량은 0 일령에서는 측정되지 않았고, 21 일령에서는 $\mathrm{GDP}$ 구가 다 른 구에 비해 유의적으로 놀은 함량을 나타내었다 $(\mathrm{P}<0.05)$. 이상 의 결과로, 생강 건조분말은 초유의 $\mathrm{IgG}$ 함량과 자돈 혈청 $\operatorname{IgG}$ 함 량을 개선시키는 효과가 확인되어 모돈 사료의 유질개선용으로 활 용이 가능할 것으로 판단된다. 


\section{인 용 문 헌}

Aeschbach, R., Loliger, J., Scott, B. C., Murcia, A., Butler, J., Halliwell, B. and Aruoma, O. I. 1994. The antioxidant actions of thymol, carvacrol, 6-gingerol, zingerone and hydroxytyrosol. Food. Chem. Toxicol. 32:31-36.

Afshari, A. T., Shirpoor, A., Farshid, A., Saadatian, R., Rasmi, Y., Saboory, E., Ilkhanizadeh, B. and Allameh, A. 2007. The effect of ginger on diabetic nephropathy, plasma antioxidnt capacity and lipid peroxidation in rats. Food Chem. 101:148-153.

Akers, R. M. 2002. Lactation and the mammary gland. Iowa State Press, Blackwell Publishing Company, Iowa. U.S.A., pp:96-99.

Antipatis, C., Rooke, J. A., Ewen, M. and Ashworth, C. J. 2001. Both moderate vitamin A deficiency during pregnancy and birth-weight affect piglet immunity. Proc. Nutr. Soc. 60:72A.

Blecha, F., Pollmann, D. S. and Kluber, E. F. 1986. Decreased mononuclear cell response to mitogenes in artificially reared neonatal pigs. Can. J. Vet. Res. 50:522-525.

Blecha, F., Pollmann, D. S. and Nichols, D. A. 1983. Weaning pigs at an early age decreases cellular immunity. J. Anim. Sci. 56:309-400.

Chrubasik, S., Pittler, M. H. and Roufogalis, B. D. 2005. Zingiberis rhizoma: A comprehenzive review on the ginger effect and efficacy profiles. Phytomed. 12:684-701.

Dügenci, S. K., Arda, N. and Candan, A. 2003. Some medicinal plants as immunostimulant for fish. J. Ethnopharmacol. 88:99106.

Fuhrman, B., Rosenblat, M., Hayea, T., Coleman, R. and Aviram, M. 2000. Ginger extract consumption reduces plasma cholesterol. inhibits LDL oxidation and attenuates development of atherosclerosis in atherosclerotic, apolipo-protein E-deficient mice. J. Nutr. 130:1124-1131.

Göransson, L. 1990. The effect on late pregnancy feed allowance on the composition of the sow's colostrum and milk. Acta Vet. Scand. 31:109-115.

Hendrix, W. F., Kelley, K. W., Gaskins, C. T. and Hinrich, D. J. 1976. Porcine neonatal survival and serum gamma globulins. J. Anim. Sci. 47:1281-1286.

Heo, H. J., Kim, D. O., Choi, S. J., Shin, D. H. and Lee, C. Y. 2004. Potent inhibitory effect of flavonoids in Scutellaria baicalensis on amyloid beta protein-induced neurotoxicity. J. Agric. Food Chem. 52:4128-4132.

Kim, H. M., Moon, E. J., Li, E., Kim, K. M., Nam, S. Y. and
Chung, C. K. 1999. The nitric oxide-producing activities of Scutellaria baicalensis. Toxicol. 135:109-115.

Ko, B. S., Joo, H. J., Ma, J. Y., Park, K. J. and Ahn, S. W. 1996. Studies on availability of components in extract of Scutellariae Radix by boiling water method. Kor. J. Ori. Med. 2:496-505.

Konoshima, T., Kokumai, M., Kozuka, M., Linuma, M., Mizuno, M., Tanaka, T., Tokuda, H., Nishino, H. and Iwashima, A. 1992. Studies on inhibitors of skin tumor promotion. XI. Inhibitor effects of flavonoids from Scutellaria baicalensis on Epstein-Barr virus activation and their anti-tumor-promoting activities. Chem. Pharm. Bull. 40:531-533.

Koo, L. K., Ammit, A. J., Tran, V. H., Duke, C. C. and Roufogalis, U. 2001. Gingerols and related analogues inhibit arachidonic acid-induced human platelet serotonin release and aggregation. Thrombosis Res. 103:387-397.

Krakowski, L., Krzyżanowski, J. and Wrona, Z. 1998. Changes within particular parameters of nonspecific immunity in piglets in the post-natal period. Medycyna Wet. 54:750-752.

Krakowski, L., Krzyzanowski, J., Wrona, Z., Kostro, K. and Siwicki, A. K. 2002. The influence of nonspecific immunostimulation of pregnant sows on the immunological value of colostrum. Vet. Immunol. Immunopathol. 87:89-95.

Kubo, M., Kimura, Y., Odani, T., Tani, T. and Namba, K. 1981. Studies on Scutellariae radix. Part II. The antibacterial substance. Planta Medica. 43:194-201.

Mahmood, N., Pizza, C., Aquino, R., De Tommasi, N., Piacente, S., Colman, S., Burke, A. and Hay, A. J. 1993. Inhibition of HIV infection by flavanoids. Antiviral Res. 22:189-199.

Micklefield, G. H., Redeker, Y., Meister, V., Jung, O., Greving, I. and May, B. 1999. Effects of ginger on gastroduodenal motility. Int. J. Clin. Pharmacol. Ther. 37:341-346.

National Research Council (NRC). 1998. Nutrient requirements of swine, 10th edition. National Academy Press, Washington, DC. U.S.A.

Pinelli, S. A., Scaife, J. R., Calderon de la Barca, A. M., Valenzuela, J. R. and Celaya, H. 2001. Effect of supplementation with vitamin $\mathrm{E}$ and vitamin $\mathrm{C}$ on immune response of sows and their litters in hot environments. Proc. Nutr. Soc. 60:25A.

Platel, K. and Srinivasan, K. 2000. Influence of dietary spices and their active principles on pancreatic digestive enzymes in albino rats. Nahrung. 44:42-46.

Razina, T. G., Udintsev, S. N., Tiutrin, I. I., Borovskaia, T. G. and Iaremenko, K. V. 1989. The role of thrombocyte aggregation 
function in the mechanism of the antimetastatic action of an extract of Baikal skullcap. Voprosy Onkologii. 35:331-335.

Rooke, J. A. and Bland, I. M. 2002. The acquisition of passive immunity in the new-born piglet. Livest. Prod. Sci. 78:13-23.

Sekiwa, Y., Kubota, K. and Kobayashi, A. 2000. Isolation of novel glucosides related to gingerdiol from ginger and their antioxidative activities. J. Agric. Food Chem. 48:373-377.

Sordillo, L. M. 2005. Factors affecting mammary gland immunity and mastitis susceptibility. Livest. Prod. Sci. 98:89-99.

Statistical Analysis System (SAS). 1995. SAS/STAT user's guide, 11th edition. Version 6. SAS Institute, Cary, NC.

Tuchscherer, M., Puppe, B., Tuchscherer, A. and Tiemann, U. 2000. Early identification of neonates at risk: traits of newborn piglets with respect to survival. Theriogenology. 54:371-388.

Zhang, Y., Wang, X., Wang, X., Xu, Z., Liu, Z., Ni, Q., Chu, X., Qiu, M., Zhao, A. and Jia, W. 2006. Protective effect of flavonoids from Scutellaria baicalensis Georgi on cerebral ischemia injury. J. Ethnopharmacol. 108:355-360.

(접수일자 : 2010. 5. 6 / 수정일자 : 2010. 9. 28 / 채택일자 : 2010. 10. 15) 